educational goal: immersion in the artistic world of Chinese folk music and songs for adequate perception and performance of Chinese folk music and songs by students (visual demonstration of the performance of the work; emotional reflection, solfedging); cultural analysis of the musical and vocal art of China to identify and assimilate the national spiritual values reflected in the work (comparison of the idea and artistic images of the work with the general cultural folk tradition and with samples of musical and vocal creativity of other peoples); dialogue of musical and vocal traditions of Russia and China to identify the international component of folk musical and vocal art.

$$
\text { *** }
$$

1. Yuan Pingping. An attempt to teach Peking opera to children // Youth Studies. 2012. No. 1. P. 16-17.

2. Hou Wei. The significance of repertoire courses in the education of musical theater talents // Art Education. 2018. No. 12. P. 97-98.

3. Su Liyan. The application of the basic systems of music education in teaching of music in primary schools // Art Education. - 2016. No. 22. P. 37-38.

4. Li Wen. Children's song in a comprehensive school// Folk music. 2002. No. 6. P. 23-28.

5. Ma Xiaochun. The role of teacher in the development of children's songs // Musical education in China. 2008. No. 6. P. 28-32.

6. Jin Zhongliang. Patriotic education in secondary schools // Educational materials. 2017. No. 2. P. 41-42.

7. Zhang Lei. Patriotic feelings in Russian music // Young writer. 2012. No. 5. P. 124-132.

8. Wang Haining. How to develop singing activities in school. Beijing: Publishing House "Art and Culture of China", 2015. 380 p.

9. Jiang Lan. Additional progress in the education of patriotism and the teaching of music // Music in time and space. 2012. No. 1. P. 61-62.

\title{
Liu Tse \\ The main directions of development of patriotic education of students by means of vocal art in the People's Republic of China
}

Volgograd state socio-pedagogical University (Russia, Volgograd)

doi: $10.18411 / s r-10-04-2021-69$

\section{Abstract}

The purpose of the article is to show how modern technologies expand the educational possibilities of children's patriotic songs by enriching this genre with new means of expression, as well as the emergence of new forms of song representation (songs for movies, TV shows for children, laser shows, open-air performances, etc.). The direct participation of children in the preparation for participation in the events, performances in front of the audience, as well as the presence as spectators and the use of music teachers of these genres in the classroom have an effective educational impact on children of different ages for the purpose of patriotic education of young people in China.

Key words: patriotic education of students, the genre of school songs, vocal art, songs from children's films, children's art film, TV contests of children's songs.

Currently, the patriotic education of students through vocal art in China is not limited to school music and singing lessons, but takes place in the process of preparing children to participate in various modern projects, such as children's opera, children's musical, TV shows for children, children's performances, etc., as well as with the direct participation of children in these projects. The XXI century brought with it changes in the social, economic and cultural spheres, as well as global informatization, which made it possible to create a new environment for the implementation of the functions of vocal works (communicative, propaganda, aesthetic, cognitive, educational), as well as to expand the boundaries of school space - to organize the participation of children in various music and laser shows, open-air performances, installations, etc. The vocal art of the XXI century is undergoing significant 
changes under the influence of the intensive development of art in general: new styles and trends are emerging, different genres (song, dance, portrait, landscape, etc.) and types of art (literature, painting, music, theater, etc.) are interacting, and media technologies are being used.

The school song, which popularized Western melodies in China, is being developed in various entertainment projects, reveals the characters' images in a new way, resorting to modern technologies. The themes of school songs are still diverse - lyrical, patriotic, fairytale, comic, etc. It should be noted that among the patriotic themes, songs about the Motherland, about the nature of the native land, about work for the good of the country predominate. There are almost no songs about the war. Modern children's songs are characterized by expressiveness, simplicity and accessibility of content, positive character, and compliance with children's interests. Currently, according to the researchers, in China, the most popular songs are those created after the formation of the People's Republic of China (since 1949), as the military theme recedes into the background, putting forward the ideas of a peaceful happy working life in a new society $[1 ; 2]$.

The 2000s were marked by the penetration of modern technologies into the genre of children's songs, which significantly expanded its educational capabilities. A popular genre today, in which a children's song is presented, is a children's art film. It should be emphasized that songs from children's films are now one of the important means by which patriotic education of students in the People's Republic of China is carried out.

The following children's films and songs from these films are considered classic examples of this genre in China. In 1953, the film "Flowers of My Homeland" was released on the screens of the country, in which the song called "Let's row together with oars" was performed, which won the love of the audience. This film is a symbol of the formation of a new republic - the People's Republic of China. The main image in the song is flowers floating peacefully on the transparent water surface. The water surface is a new country where children travel (in the form of floating flowers). The transparency of the water surface symbolizes comfort and peaceful working life in the new society, the flow of the river - the leading role of the Communist Party. According to the researchers, this song is mandatory for studying at the school singing lessons, as it is directly related to the patriotic theme. It is also played at the annual Children's Song Contest and on the national radio [3; 4].

The film "The Diaries of My Sisters" (1956) is considered in China a classic of children's films about happy life in a beautiful country. The song "Swallow", specially written for this film, was immediately remembered by the audience thanks to a simple text in the form of a dialogue and a lyrical melody based on folk motifs. The swallow in this song symbolizes a curious child who shows a sincere interest in the world around him, and never ceases to admire the beauty and richness of his native nature [Ibid.].

In the 1960s, a children's film with a pronounced patriotic title "We are the heirs of Communism" was released. The song for this film, written in the genre of a school song "Pioneer Song", becomes the anthem of the Chinese pioneers, and, thanks to its rhythmic march-like melody, is traditionally performed during solemn mass events. The lyrics of the song convey the desire of young pioneers to follow the decisions of the Communist Party, to keep sacred and multiply the achievements of their predecessors, to take an example from national heroes, so that they can rightfully consider themselves the heirs of communism. This song is always performed by a children's choir and serves as an effective tool for educating the spirit of collectivism and cohesion among schoolchildren [5].

In the 1970s, the theme of the pioneer song was continued by the film "Red Stars", in which the "Star Song" was performed. The song also has a marching rhythm and a playful melody, symbolizing youth, strength, love of life, and readiness for new achievements. The "Pioneer Song" from the previous film and the "Star Song" vividly symbolize the image of the Chinese pioneer - a worthy successor of the glorious traditions of the Communist Party, a 
brave and determined man, a true patriot of his people and Homeland. Both songs are performed by students of secondary school age in singing lessons and at mass events [6].

In modern China, children's song TV contests are very popular. They also serve as an important means of patriotic education of the younger generation through vocal art. Competitions have different scales - from regional and national to international. Preparation for these events instills in students great responsibility, hard work, patience, perseverance, perseverance, the desire to win, which creates a favorable basis for the education of patriotic qualities of the individual.

It should be emphasized that TV contests of children's songs are a more modern form of representation of children's songs, the foundations of which are laid by classical concert performances on stage, therefore, this is one of the modern trends in the development of educational work with children through vocal activity. The new form of vocal activity has a number of differences from the traditional concert performance: the theme of vocal works is limited by the requirements of the competition commission; to convey the artistic image of the work, the contest participants must possess not only vocal, but also acting skills; an important element in the transmission of the artistic image is the participant's costume, which must correspond to the ideals of beauty, aesthetics, and style accepted in society. In the last decade, the most popular children's songs of patriotic themes that won prizes in TV contests are: "Fields of my Homeland", "Happy Childhood", "Mother's Story about the past", "My beloved China", "Let's row together with oars", "Pioneer Song", etc.

Among the prestigious TV contests that began to be held at the beginning of the new millennium, we should mention the Children's Song Contest (Ningxia), organized since 2010, and which has become an annual event. The songs performed at the contest have a patriotic theme, the purpose of which is to sing the beauty of the native land, glorify the heroic past of the country, as well as the labor exploits of the Chinese people [7].

Since 2009, a competition for young performers has been held, which can be attended by students of junior and middle classes of general education schools (Beijing, Shanghai, Xiamen). The competition also has a patriotic focus, as the main goal is to preserve the national musical traditions, reflect ancient poetry in modern song, which will contribute to the development of China's artistic culture. The songs of the modern children's composer $-\mathrm{Gu}$ Jianfen, who created a number of new school songs, combining ancient poetry and modern melodies (for example, "Spring Song", "Holiday Song", etc.), are very popular.

Since 2011, an annual children's song contest has been held in Guangzhou, which was established in the honor of the anniversary of the founding of the People's Republic of China. The main theme of the contest is the glorification of a great nation, so all the songs are dedicated to the Motherland, the Chinese people, and their native country. The contest has a pronounced patriotic character. The conditions of participation provide for different forms of performance from each participating city: solo, choir and ensemble. Popular songs that are heard at the contest are "Boundless Expanses of the Motherland", "I love you, my native China!", "My great country", "I love Beijing Square", etc. [8].

It should be noted as a new trend in the patriotic education of children by means of vocal art, the organization of song contests for participants of preschool age. This competition was first organized in 2012 in Wuhan, and is timed to coincide with the International Children's Day. The theme of the contest songs is dedicated to happy childhood in their native country, which is close and understandable to every child and brings up love and respect for their Homeland, home, and family. Popular songs that are heard at this annual competition are "My hometown", "We are friends!", "The world is filled with love", "We sing on the day of the Holiday", etc. This competition, as well as the previous ones mentioned above, has its own TV version on central television [9].

Children's song contests help young performers not only try their hand at art, demonstrate their skills and the results of serious work, expand the boundaries of national music, but also educate children in the spirit of patriotism and respect for the cultural heritage of China. 
Conclusions. The development of patriotic education of students by means of vocal works in the People's Republic of China is manifested in the following main directions:

- patriotic education acquires a continuous interdisciplinary character, filling all types of educational work with patriotic content;

- educational work is not limited to school music and singing lessons, but takes place in the process of preparing children to participate in various modern musical projects (children's opera, children's musical, children's TV shows, laser shows, open-air performances, installations, etc.), as well as with the direct participation of children in these projects;

- the new information environment and media technologies allow us to expand the possibilities for the implementation of the functions of vocal art (communicative, propaganda, aesthetic, cognitive, educational);

- in connection with the changes in the social, economic and cultural spheres of society, vocal art undergoes noticeable changes under the influence of the intensive development of art in general (the emergence of new styles and trends, the mutual influence of different genres (song, dance, portrait, landscape, etc.) and types of art (literature, painting, music, theater, etc.).

- the school song, being developed in various projects with the help of modern technologies, reveals the images of the characters in a new way due to the predominance of peaceful, rather than military themes (among the patriotic themes there are songs about the Motherland, the nature of the native land, the family, work for the good of the country, but there are almost no songs about war).

$$
* * *
$$

1. Wang Yu. The history of Chinese song. Beijing: Publishing house "Folk Music", 2012. 367 p.

2. Zhao Chunlei. Evolution of the style of writing patriotic songs in the new era // Musical Creativity. 2019. No. 8. P. 106-112.

3. Go Ying. On the education of patriotism in musical evaluation // Information about Science and Technology. 2016. No. 29. P. 127-129.

4. Liu Liping. Film and television // Music and Patriotism. 2007. No. 14. P. 65.

5. Yu Zhong, Wang Jie. Discussion of Li Shutun's creativity-patriotic feelings in school songs // Art Education. 2019. No. 12. P. 58-60.

6. Yang Yuchen. Teaching music and education of patriotism // Chinese Music Education. 2018. No. 1. P. 44-46.

7. Chen Yulin. Love music, love the Motherland-how to develop students' patriotism in music teaching // Northern Music. 2018. No. 16. P. 32-41.

8. Chen Haochun. Education of patriotic qualities in primary school students // Education in Gansu. 2014. No. 20. P. 115-118.

9. Zhong Zhenglin. Listen to the song of China // Shikan Magazine. 2017. No. 17. P. 15-16.

\section{Fu Ying \\ Pedagogical potential of visual activities in environmental education of students in China}

Beijing University (China, Beijing)

doi: $10.18411 /$ sr-10-04-2021-70

\section{Abstract}

Our research identifies the role of visual activities in the environmental education of schoolchildren, so the goal of this article is to analyze the concepts of modern Chinese scientists who are directly related to this problem.

Key words: visual activities, environmental education, ecological culture, cultural values, ecological thinking. 